\title{
Experiencing the enchantment of place and mobility
}

\section{Bærenholdt, Jørgen Ole}

Published in:

Journal of Consumer Culture

DOI:

10.1177/1469540516635415

Publication date:

2016

Document Version

Peer reviewed version

Citation for published version (APA):

Bærenholdt, J. O. (2016). Experiencing the enchantment of place and mobility. Journal of Consumer Culture, 16(2), 393-411. https://doi.org/10.1177/1469540516635415

\section{General rights}

Copyright and moral rights for the publications made accessible in the public portal are retained by the authors and/or other copyright owners and it is a condition of accessing publications that users recognise and abide by the legal requirements associated with these rights.

- Users may download and print one copy of any publication from the public portal for the purpose of private study or research.

- You may not further distribute the material or use it for any profit-making activity or commercial gain.

- You may freely distribute the URL identifying the publication in the public portal.

Take down policy

If you believe that this document breaches copyright please contact rucforsk@kb.dk providing details, and we will remove access to the work immediately and investigate your claim. 


\title{
Experiencing the enchantment of place and mobility
}

\author{
Jørgen Ole Bærenholdt \\ Roskilde University, Denmark ${ }^{1}$
}

\begin{abstract}
Dumbledore: Of course it is happening inside your head, Harry, but why on earth should that mean that it is not real?

(J.K. Rowling: Harry Potter and the Deathly Hallows: 579)

[...] non-representational theory may be understood as radically constructivist, in that, echoing Latour [...], it avers that everything is really made-up, but is no less real for this [see Thrift ...] (Andersen and Harrison, 2010: 9)
\end{abstract}

\begin{abstract}
Experiences of place and mobility play central roles not only in what was traditionally understood as tourism, but also in the broader practices of travelling and visiting sites and sights. On the one hand, such experiences are performed to an extent where it is difficult to isolate the sites and movements experienced per se, since visitors and travellers take part in 'doing' places and mobility. On the other, experience sites and routes stand out with specific traces and characteristics affording some - and not other - experiences. This paper discusses conceptual understandings that may help to better analyse what it takes to perform tourist sites. Following a discussion of Walter Benjamin's way of understanding experiences as Erlebnisse, I suggest that ideas about multiplicity and absence-presence in Actor-Network Theory can develop new insights into how place and mobility are experienced in several layers of reality. To better understand experiences taking place in intersections between realities, J.R.R. Tolkien's concept of how real enchantment produces a Secondary World suggests that we see fantasy as real, and this proposition is compared to Georg Simmel's more modernist suggestion that experiences (Erlebnisse) are practised as living adventures, where intersecting worlds are not apart from each other. These practices are performed in restless mobilities among places, where the connections and hints between place and mobility are central in making absence-presence tensions produce experiences. Finally, the paper discusses how the analysis of experience is related to the professional, experimental work of building a tourist attraction, exemplified by the Viking Ship Museum in Roskilde.
\end{abstract}

\section{Keywords}

Absence, experience, enchantment, mobility, place, tourism

\section{Introduction}

People seek experiences; experiences are wished for and desired. And few experiences mean so much to people as tourist experiences of place and mobility. Enchantment is a complex concept describing the experience of something really fantastic, beyond one's own subjective experience. Speaking of my enchantment with a place is much less important than the enchantment of the very same place, since the latter proposition suggests multiple

\footnotetext{
${ }^{1}$ Jørgen Ole Bærenholdt, ENSPAC, Roskilde University, P.O. Box 260, DK-4000 Roskilde, Denmark.

Email: job@ruc.dk
} 
realities in places' complex histories, geographies, cultures, architecture, etc. While remaining inside our heads, the real enchantment of a place refers to experiences that do not belong only to the minds of humans. The place also affords specific traces that are not immediately present. As Benjamin saw it, there are 'utopian traces which lay dormant within material objects [...]' (Latham, 1999: 456). Experiences include important material things that ' $[. .$.$] are also eventful' (emphasis in original, Braun and Whatmore, 2010: xxi). Thus,$ experiences occur through relational accomplishments (Svabo et al. 2013: 316) or tourismscapes (Van der Duim et al., 2013), where psychological understandings of the experiencing individual subject (Jantzen, 2012) cannot fully comprehend how tourist experiences unfold. Such experiences involve more than just having a great time with touring consumption. Experiences include the enchantment of specific places and mobility routes with all their real and eventful things full of traces.

This paper is about experiencing the enchantment of the real that is also made-up and performed. It deals with tourist consumption as a case of how people engage with the world. It is written in search of a better analysis of what it takes to perform tourist sites. What does it take to make experiences (Erlebnisse)? What are the triggering features of fascinating and fantastic experiences? How is it that experience, place and mobility seem to depend on each other? And how can analytical insight be involved in making better spatial designs at tourist attractions?

Experience as a concept has not been a central interest in consumer studies. Research in consumption has concentrated more on the role of consumers, their empowerment, culture and creativity (for example Halkier, 2010), while issues of what is exciting and enchanting seem to belong to another sphere. When experience occurs as a central concept, it is either from a marketing perspective (Carù and Cova, 2003) or from a philosophical methodology perspective (Thompson et al., 1989), but not as a concept that needs theoretical sophistication in itself. Marketing and consumption approaches are generally not occupied with the extraordinary, sensational and pleasurable. But this is partly different when it comes to research into the consumption and experiences of places (Lonsway, 2009; Miller et al., 1998; Urry, 1995), since places (and mobilities) seem appropriate to approach from an experience perspective. Recent research in consumer culture on place and mobility interestingly focuses on technology-mediated experience and multi-site performance (Degen et al., 2015; Hui, 2012; Nielsen and Møller, 2014), but still the concept of experience itself is not central. In line with this, material culture studies of things (Gregson, 2007; Miller, 2010) are more interested in how people live with and accommodate things in their everyday lives - than with excitement and experience. It is the intriguing introduction to the experience economy by Pine and Gilmore (1999) that has put experiences on the agenda, and Lonsway (2009) has translated this way of thinking into architecture and place making. This produced a keen and critical interest in how place gets designed for consumers, for example in retail services, but not really a deeper insight into the concept of experience. It seems that the most profound interest in experiences has in fact been in tourist research and its preoccupation with place and mobility, which is also the background of this paper.

Tourist experiences crucially involve people travelling to places, whereby mobility enables presence in those places. Tourist experiences take place in places, where experiences also depend on how tourists themselves take part in performing places (Bærenholdt et al., 2004; Coleman and Crang, 2002; Edensor, 1998, 2001; Haldrup and Larsen, 2009; Minca and Oakes, 2006). Thus, this paper seeks only to understand one of two main versions of the socalled experience economy (Pine and Gilmore, 1999, 2007). This version is the one based on 
the meeting of people, present-in-place, while the other version of the experience economy is about manufactured consumer goods, transported from producers to consumers (Sundbo and Bærenholdt, 2007). Although there are obvious intersections between the two versions, for example between the tourist and the cinema experience of New York, the distinct feature of tourist experience is the presence of the tourist, taking part in performing the experience. This also implies that the specific design of the place has a decisive influence on multisensual experiences. Places are eventful and afford some tourist performances better than others. While consumer research has been more occupied with consumer goods, it seems that experiences, and enchantment I will add, are more acknowledged in tourism where people perform-in-place.

While there is already a rich literature on tourist practices and performances, and also a literature of the more managerial aspects of the experience economy, even these two bodies of literature have a gap in their more precise knowledge about what makes the better, more rewarding or really pleasurable experiences. Existing knowledge can analyse how people do tourism and how experience economies work, but the conceptual tools needed to arrive at deeper understandings of what makes experiences are lacking. Of course, there is a third rich psychological framework for understanding experiences (Jantzen, 2013), but this is a framework focusing on the subjective experience of the individual, thereby not integrating what tourists sites do. Better investigations of what tourist sites do in terms of experiences find inspiration in the relational ontologies embedded in studies of tourist performance, mobility and the affordance of places and designs inspired by recent studies of tourist performance enacting material culture approaches, Actor-Network Theory (ANT) and NonRepresentational Theory (NRT). This is a complex paradigm that also includes inspiration from Gibson's psychology of affordance, especially as transmitted through Tim Ingold's phenomenology (Ingold, 2000). It suggests that experiences could be better understood as relational accomplishments, beyond traditional dualisms, such as those between subject and object, mind and nature, and body and environment.

This kind of relational approach is able to unpack the intricate intersection of mobility and place in contemporary societies with people on the move and in search of places. The literature on mobility and place (Amin and Thrift, 2002; Bærenholdt and Granås, 2008; Cresswell, 2004, 2006; Massey, 2005; Urry, 2007; Verstrate and Cresswell, 2002) offers a sound basis for understanding the experiences of place and mobility in a world where mobile touring to visit places - touring consumption - is a part of everyday life. This extends far beyond traditional tourist trips on holidays. The experience of place and mobility is fundamental to living in, being in and dealing with the world. It is more or less a fundamental need of human life; the tourist way of engaging with the world has become an embedded and embodied part of life. In spite of, and thanks to, the many virtual and imagined kinds of world involvement, bodily presence with place and mobility still has vital importance for how we can live with and experience the world. I say place and mobility, not because of a contradiction, but because they work together. These days it is hard to think of places without the mobilities leading to and connecting them. Likewise, to think of mobility without the places we are going to does not make sense. Neither place nor mobility is abstract; they are utterly concrete. Moreover, they are full of paradoxes, such as the calming and restful effect of the restless acceleration of touring people.

Experiencing places and mobility this way is about excitement and inspiration, and in this way modernist experiences tie into how the world is enchanted. While experience as a relational accomplishment is not much investigated in the literature about place, mobility 
and tourism, this paper suggests that relational ways of approaching experience can be traced in a number of, mostly 'classical', works, discussed in the following sections.

\section{Experience: Erlebnis versus Erfahrung}

Walter Benjamin provides the classic inspiration for understanding experiences in capitalism. This comes, not least, from the unfinished fragments called The Arcades Project (Das Passagen-Werk in German, Benjamin, 2007), which Benjamin left behind before his tragic death in 1940 (Buck-Morss, 1991). This work deals with experiences in the nineteenth-century development of consumption in Paris, but has a much broader relevance. Congruent to Benjamin's ideas, Jane Bennett (2001) and Georg Ritzer (2005) understand fascinating and fantastic experiences taking place in socio-material relations as enchantment.

Benjamin's fragmentary works fundamentally inspire an understanding of what experience is about. It is not about pretence and simple magic illusions, but about real fantasies through distractions, distances and absences, opening up the possibility for people to take possession of objects, spaces and worlds, present and enlivening. As Benjamin stresses (2007: 246) 'the true method to make things present to us, is to imagine them in our space, not us in their space [...]. It is not us giving in to them, they step into our lives' (my translation from the Danish). 'Bringing things nearer' has become a passion of the masses, taking possession of them (Benjamin 1998). Experiencing for Benjamin is about taking inspiration from distractions and surprises to make us live up and change our ways of life.

In reading Benjamin, Kevin Hetherington (2007) suggests that we should understand how consuming subjects 'take possession' of commodities. A central point in Hetherington's book is his discussion of the two meanings of the English word 'experience': (in German) Erfahrung and Erlebnis. He explains the kind of dialectics between the two, where Erfahrung is about contemplation by the producing subject, only gazing at the world. Hetherington explains that Benjamin's contribution is to shift attention to Erlebnis for the modernist forms of reception. Hetherington follows Benjamin closely and explains Erlebnis as being about glancing rather than gazing at the world in ways of experiencing where distraction always plays a role. I suggest that this deeper way of elaborating the difference between the two concepts is preferable as compared to other ways of dealing with the two words in terms of their being along a continuum (see Jantzen, 2013: 150). In parallel to Hetherington, Soile Veijola suggests Erlebnis is to be associated with adventure and event, while Erfahrung relates to being familiar and skilful with things and to observation (Veijola, 2006: 83). Benjamin suggests making adventures real and letting the unexpected take place.

Hetherington suggests avoiding the cultural pessimist readings of commodity found in the tradition of Karl Marx, where consumption is associated with illusion and pretence. In Marx's Capital, the illusion of the commodity lies in seeing objects with no recognition of working processes having produced them. The commodity thus cheats the consumer, since relations are hidden. The nineteenth-century magic lantern show, Phantasmagoria, where people only saw the shadows of things, becomes Marx's metaphor for the same critique. While Marx basically recognises the effects of objects, his problem was that he could not trust the objects' effects. Since Marx sees true subjects only as those of producers, he has a romantic approach to the worker. He has no understanding of the experiencing consumer. Marx's analysis of fetishism is frozen in a single moment; it does not acknowledge how consumers can reflect (Hetherington, 2007: 70). But experiences (Erlebnisse) are reflexive in the modernist sense, which is also the reason why experiences need to be performed to 
take place. Bennett (2001) has a similar take on this issue in her critique of Horkheimer and Adorno.

Benjamin was more a modernist, using montage techniques to open up the possibility of otherwise hidden traces. Benjamin's approach to fetishism is thus more mythical; it also looks for wish-images and new potentials buried in the already existing. In his Expóse 1939 in the Passagenwerk Benjamin explains his interest not only in the theories and ideologies of new ways of life of the nineteenth century, but also in how these changes produce new sites for experience that can be sensed in presence (Benjamin, 2007: 24). His interests are thereby also in illuminating the desires of people in modernity. Central to people's new 'experiences' are the ways in which they are distracted through consumption. 'Distracted' is associated here with modernist Erlebnis through consumption, from which people cannot escape. Any possible progress has to take place through the realities of Erlebnis; not beyond or outside of it (Hetherington, 2007: 100). To Benjamin, experience in the modern, capitalist economy is not about truth, but about the real.

Hetherington (2007: 106-129) traces the genealogy of the modern consuming subject. He uses the metaphor of the 'flâneuse', strolling and browsing the city, beyond the gazing flaneur, glancing over goods on display in a kind of un-decidable, paradoxical space.

Consumers act in a constant combination of proximity and distance to goods, but this is not an illusion; things are really accessible and it is possible for the consumer to take possession of goods.

Throughout his book, Hetherington plays with ideas of absence-presence developed in earlier papers (Hetherington, 2002) and shared with Law and Mol (2001, and see next section of this paper). This goes not only for the flâneuse, but also for kitsch objects such as souvenirs of other places at home and the 'presence of what is not' in the museum (Hetherington, 2007: 174). The idea of absence-presence suggests that what is present depends on what is made absent. Here absence is not absence as such, but relationally a kind of manifest absence or what Hetherington (2002: 182) called 'figural presence of absence'. The idea implies that what is present depends on what is made absent, since the absent plays a role in presence. This is for example the idea of the souvenir: it reminds one of a place visited, which is now absent but thereby exactly somehow present. Thereby, the absentpresent points to the specific and utterly concrete meaning and impact of certain places.

This is in line with Mike Savage's (2000: 47) argument that Benjamin had a particular take on the city, as compared to his take on the mass production of mechanical reproduction objects where the aura of the original disappeared (Benjamin, 1998). Benjamin points to cities' distinct characteristics - why for example Paris, Moscow and Berlin can never be the same. Such places cannot be mass-produced. They keep their particularity. Thus in paradoxical ways, cities are full of aura. Meanwhile they are also experienced in a state of distraction, and this makes a productive tension: They are full of potential for memory and redemption, but this is not because of any traditional, essentialist aura. The experience of a place does not come only from the original place. It emerges through the distraction people perform in experiencing built environments. It is precisely the combination of the aura of the particular and the distracted experience that makes the potentials of the urban experience. Though not a central concept in Benjamin's and Hetherington's work, enchantment - contra pretence - is exactly about these doubles. Experiences, as Erlebnisse, emerge and unfold in the intertwinement of place and mobility, experienced by people who move through, touch 
and activate layers of eventful adventures associated with places that are multiple and performed.

It is interesting that almost all examples of 'taking possession' of environments and objects in Hetherington's work and Erlebnis and the city from Benjamin are in fact about places, and if they are not directly about places, they are about places in fiction. These sites and means of experiences are precisely much more than abstract; they are particular places where people can be present and take part in performing experiences, and where the particularity of material objects has a specific impact (Latham, 1999). This suggests that experiences, still in the modernist form of Erlebnisse, have some sort of fundamental connection with the multiple dimensions of places and mobilities. Since experiences are about vital engagement with particular worlds, they always imply some kind of involvement with being in and going to places, moving along particular routes, always being somewhere and on the move to somewhere else.

\section{ANT, multiplicity and place}

Ideas about experience in Benjamin's work appeal to a number of recent, interesting works on tourism, festivals and museums employing ANT approaches to analyse the performance of experiences. Mostly the inspiration from ANT has been on the 'producer' side of experience economies, responding to questions on how experiences are enacted among professionals and volunteers at tourist sites (Jóhannesson, 2007; Ren, 2009; Pedersen, 2010; Van der Duim et al., 2012). ANT approaches have helped us to better understand the complex spatial orderings of tourism, and here, especially, inspiration from Mol and Law's (1994, 2002; Law and Mol, 2001; Mol, 1999) thinking on topologies has been crucial (Jóhannesson and Bærenholdt, 2009, and see Bennett, 2001 and Bingham and Thrift, 2000 on Latour). Their way of thinking about ontological politics and the metaphors of region, network, fluid and fire have inspired works on the enactment of Viking tourism in Iceland (Jóhannesson, 2005, 2007; Jóhannesson and Bærenholdt, 2008). The notions of fluidity and fire have been particularly helpful in understanding the enactment of tourist places. Fluidity demonstrates how development projects in tourism are often more successful, if original plans are constantly rethought and remade as part of a process of mobilising people and things locally. The metaphor of fire especially shows how energy and engagement can make projects run through 'sparks' of an entrepreneurial type, mobilising efforts across otherwise disconnected planes. In particular, post-ANT approaches as found in Mol and Law also help in addressing virtual planes, the concepts which Farías (2012: 128) found missing in Latour.

ANT has inspired studies of the materiality involved in performing tourism (Bærenholdt et al., 2008; Haldrup and Larsen, 2009), but the contribution of ANT towards deeper understandings of experience and enchantment is sparse. Svabo's research (2008, 2010 and Svabo et al., 2013: 318-20) concerning how portable objects (or media) are used in visiting a natural history museum found that the various portable objects enacted multiple realities for people visiting the museum. Furthermore, there are intersections or interferences between the various realities; or we could say between various experiences. 'The museum visit consists of chains of shifting, patterns of interference, fluid turbulences and flickers between presence and absence' (Svabo, 2010: 272). ANTs contribution, and most significantly in its 'second generation' or 'post' version as formulated by Mol and Law, is its consequent focus on the making of the world, as a kind of ontological politics similar to the radical constructiveness in NRT (Non-Representational Theory, see opening quote). Realities are thus basically enacted (Mol, 1999). Furthermore, in complex ways realities are 
multiple (Mol and Law, 2002). The multiplicity of realities, and therefore also of experiences, comes from the multiplicity of practices enacting the world.

Shifts and tensions among multiple realities, crucial in experiences, also involve relations between presences and absences. Law explains this about multiple spaces in more basic terms as follows: 'in order to make an object in one space, it may be necessary to work in another' (2002: 97). In relation to the idea of experience economies, this means that the enactment of experiences depends not only on multiplicities per se, but also on the intersection between multiple layers combining presences and absences. In other words, experiences also play on objects, spaces and realities made absent (for example made distant).

The experience of place can be rethought with multiplicity and absence-presence in ANT. Contrary to most discussions, here ANT's contribution does not come from material actants, but rather through relational ways of understanding how worlds (plural) come into being. ANT's relevance is first and foremost through its focus on ontological politics (Mol, 1999), where the performance of place depends on how the absent is managed (Law, 2002). Continuing Hetherington's ways of thinking about absence (see the above section), it is important to stress how important absence is, since much of the experience is about hinting at the absent. This role of the absent is almost the opposite of how absence was employed in a consumer culture study by Jenkins et al. (2011), which was also inspired by ideas from John Law. In this study absence was rather about forgetting that the means of simple pleasures in everyday life are commercial, not exactly something to be hinted at. Compared to this study, I suggest that absence is not about omitting but about hinting and connecting to the absent.

In relation to tourist destinations, managing absence in relational ways is vital and ties deeply into how places are enacted via relational assembling of multiple actors, trying to make fragile tourist experiences take place in every new season (Bærenholdt, 2012). I have tried to argue for the compatibility of such ways of understanding taking inspiration from Benjamin's fragments. The next section is an intermezzo taking the discussions of experiencing place and mobility into the enchanted Secondary Worlds of fantasy in an attempt to clarify the notion of enchantment as a qualification of what is meant by experience, in the meaning of Erlebnisse.

\section{Intermezzo: Enchantment and the real}

Experience is associated with various qualities: Authentic, magic, fantastic, pleasurable and enchanting are among those. In his essay On Fairy-Stories (1997) the great creator of fantastic worlds J.R.R. Tolkien stressed how realism already has all the necessary ingredients of fantasy. He was thus in search of words for how people are really, bodily inside the 'Secondary World' of fantasies. He thought of this as a kind of 'elvish craft', for which he thought magic is the wrong word, one that should be reserved for magicians (Tolkien, 1997: 142). Instead of magic, he proposed 'enchantment' for 'this elvish craft', to which fantasy also aspires. He explained: 'Enchantment produces a Secondary World into which both designer and spectator can enter, to the satisfaction of their senses while they are inside; but in its purity it is artistic in desire and purpose. Magic produces, or pretends to produce, an alteration of the Primary World' (Tolkien, 1997: 143). Enchantment thus takes place because both the designer and the spectator take part; this is not the case with magic. For Tolkien the Secondary World is crucial to fantasy, but this is so exactly because of the 
realism of the Secondary World (see also Bærenholdt and Haldrup, 2004: 86 on fantastic realism). He thus suggested that fantasy is fundamental and natural to human practice, and, it is worth stressing, he saw fantasy and reason as very similar to each other. 'For creative Fantasy is founded upon the hard recognition that things are so in the world as it appears under the sun'. He continued: 'If men really could not distinguish between frogs and men, fairy-stories about frog-kings would not have arisen' (Tolkien, 1997: 144). The fantastic experience - the enchanted Secondary World - of frog-kings thus depends on recognising the difference between frogs and men in the first world.

In this way, enchantment and fantasy are at the core of experiences. For sure, Tolkien, in his discussions of fairy-stories, did not directly address contemporary issues of touring consumption, but the dichotomies he played with can inspire contemporary debates on, for example, authenticity, performance and the real. Although this is not the place to discuss authenticity, it is inspiring that Knudsen and Waade (2010) in reflecting upon Pine and Gilmore's book on Authenticity (2007), and inspired by Wang's (1999) classical article, see authenticity as performative - something done - associated with the social construction processes of authentication. Performative authenticity - or connective authenticity (Bærenholdt et al., 2008) - is thus not about truth. Pine and Gilmore explain that authenticity is bound to the real and to real-fake tensions; and not to what is true, as opposed to false (Pine and Gilmore, 2007). It is the same reference to reality that we saw in relation to Tolkien's frog-kings.

The concept of enchantment taken from Tolkien and the enchantment of real worlds inspire the analysis of experience. However, following Benjamin, we need to address the multiplicities of experiences in a more modernist way.

\section{Mobility and experiences in second modernity}

Georg Simmel was one of the first to provide an understanding of touring experiences from a more modernist perspective, and Benjamin's work should be seen a further development of ideas already presented in Simmel. Furthermore, John Urry (2007) argues that Georg Simmel is also the father of mobility thinking, ready to be driven out of the garage again. This paper argues that experiences and mobilities are highly interdependent in modernity. And this idea finds support in Simmel's essay on the fairy-story Das Abenteuer (1986). In the essay he argues that fairy-tales, as artwork, work through being practised as living adventurers.

Simmel thus adds 'a modernist twist' to Tolkien's 'classic' essay On Fairy-Stories (1997). For Tolkien's classic fantasy is of another kind than the distracted, mobile Erlebnis, since it is the making of the contemplative, fantasising subject that thinks all too much. With mobile Erlebnis, people are thrown out into the mall stream of floating stimuli, out of their control. The distracted experience of mobility is that of the pleasures of multi-level consumption across worlds, destabilising the stable, thinking, 'classic' subject. Thus the mobilising experience is in this way more than reading and identifying with a fairy-story whilst sitting in one's armchair. Though firmly engaged in arguing for a materialist approach, Jane Bennett (2001) in her thorough search for enchantment in political philosophy thinks of enchantment as associated with the momentary surprise and sonority (chanting) in experience still in a somehow 'traditional' way. 
Mobility promises connections between worlds. It has to do with the challenges of 'living through, living up to, running through, being part of, accomplishing' (Löfgren, 1999: 95) associated with Erlebnis. It involves serious and factual engagements in reality, letting worlds impact you, being engaged with risk (Buciek, 2001; Kesselring, 2008), balancing between safe and unsafe, secure and insecure, certain and uncertain. Erlebnis means to take part in adventures along several and contingent tracks in fluid ways, letting things happen, casting one and others into the non-predictable. With Erlebnis, fairy-tales are more than imagined realities. They belong to the deadly serious experiences of mobility, where bodies are invested and thrown into connections. These are mobilised experiences where distraction, interruption and confusion cannot be escaped.

Addressing Das Abenteuer, Simmel (1986) already hints at the modern possibility of adventures being lived out, outside of the fantastic realms of writers like Tolkien. In classic fairy-stories, Secondary and Primary Worlds are still worlds apart, one the fairy-story, the other the classic experiencing (Erfahren) subject. But the experience (Erlebnis) of mobility transcends such boundaries, where adventures become corporeal routes to live through. Thus the experience of mobility among consumers resonates with the rationality of Knowing Capitalism (Thrift 2006) where representations are no longer apart, and sensitivity and performativity become part of the 'machine' of capitalism itself to the extent to which the illusions of its 'magic' may sometimes cause a crisis in the system itself. Under this kind of postmodern capitalism, re-enchantment works through spectacle, imitation and simulation in 'cathedrals of consumption' (Ritzer 2005). Hetherington (2007) explores how consumers under such conditions glance over goods and experiences offered in a kind of un-decidable, paradoxical space, where one can never be sure about what is present and what is absent. This way, the experience of mobility can be seen as the restless search for the fairy-stories of life.

Erlebnis is thus no longer detached from the ordinary. It is not only extraordinary moments apart from everyday life. Therefore this concept of experience differs from Victor Turner's more classic understanding of Erlebnis as reserved for the liminal, extraordinary, performative and ritual event, in contrast to 'the invariant operation of cause and effect, of rationality and common sense' of ordinary life (Turner, 1986: 42). Experiencing mobility has become increasingly woven into the everyday (Haldrup and Larsen, 2009). The kind of adventurer already proposed by Simmel has been further explored along with nondirectional mobility and characters in 'a configuration of openness and fine tuning' virtually networked with 'solidarity of connectivity' (Kesselring and Vogl, 2008: 176, 177). Experiencing mobility is about the adventures of drifting connections always in the making.

Tourism and other experience economies imply the possibility of pleasurable Erlebnisse. Yet, the classical tourist mobility was the journey of the well-governed subject experiencing (Erfahren) the world in the classical mode, in the framed gaze, still touring in first modernity. In second, reflexive modernity, mobility is revealed as 'imperfect and incomprehensive, as a God that is unattainable' (Kesselring, 2008: 84). It becomes obvious that uncertainty and the unexpected are still there, since mobility potentials only grow, but now in limitless directions. Mobility becomes something beyond the purity of order; the mobility of second modernity is contingent, unforeseeable and not the least distractive. Though the distinction between first and second modernity should only be taken as heuristic, non-essentialist and non-epochal, it does help us to understand the transformation from the classical modern subject with governed mentality, to the reflexive communities (Lash, 1994) 
and relational practices that depend on the engaged performances of oneself and others together.

It is no longer possible for the tourist, the mobile 'experiencer', to govern her/himself as a subject. Mobility has provided the vision of limitless possibilities never possible to accomplish. People try to navigate in the classical way, but with little impact, since they are exposed to the mall stream of the stimuli of tourism, consumption and experience economies. These are performances not of the individual as a terminal or a navigator, but of the drifting and restless scapes of movement and mobility potentials (motility), however unaccomplishable they are. To cope implies the tactics of De Certeau (1984), but also exposure to cities as 'means of mass producing and acculturating bodies' (Amin and Thrift, 2002:

103). Movement becomes, therapeutically, the way to cope with restless and limitless mobility potentials: To move, to get calm, to rest, coping with uncertainty. Tourists are thrown into relational performance, where one another depends on each other. To experience the enchantment of place and mobility implies tourist co-performance.

\section{Experimenting: a case of enchanting spatial design}

So far, the question of what it means to experience enchantment and the close relation between place, mobility and experience has been the topic of this paper. Benjamin's (2007) initial inspiration and Hetherington's (2007) reading of him pointed to Erlebnisse and distraction. This led to absence-presence and multiplicity in post-ANT approaches, proposed by Mol and Law, adding new perspectives to our understanding of experiences. To understand enchantment, fantasies and fascinations, we visited Tolkien's classical notion of the fairy-tale conceptualised as Secondary (and maybe more) World(s). This was followed by Simmel being driven out of the garage once again to account for the living adventurer in second, reflexive modernity. Thereafter, the spatial paradoxes apparent in both Simmel's and Benjamin's work led to the close connections between mobility and experience. And still, place and mobility come together, both working in their concrete, non-abstract realness. The paper has argued that experiences are about the enchantment of the multiple realities of places and mobilities in a world that is uttermost real, made and multiple.

But how can professionals in the experience economy help make better, more enchanting experiences? In tourism, much effort comes from learning by doing among hosts and museum curators with backgrounds in subjects like arts, history and archaeology together with architects and planners. While it is obvious that pragmatist approaches of learning by doing are very helpful, it is also worth considering whether visitor experiences could be enhanced and enchanted by working more deeply with the enactment of experiences in practice. This perspective reopens the question of Erfahrung versus Erlebnis, since the focus on the producing experience economy may lead us to reconsider a concept of Erfahrung beyond Hetherington's explanation of it as about only the producing subject, skilfully gazing a familiar world. Obviously, the concept of experience and its translations can hardly be stabilised. Derek McCormack states: 'Experience is one of the most problematical of philosophical terms' (2010: 201) and by looking into the concept of experience in the pragmatist tradition, he found a concept of experience as Erfahrung that is non-subjective but connective and with a future orientation. Experiences are thus highly associated with experimenting. He writes: 'Pragmatist experience is therefore conceived as the relational stuff of the world, a processual thisness that is only ever grasped in the course of its transitional immediacy, an immediacy that is always as virtual as much as actual [...] always becoming more than itself' (McCormack, 2010: 205). 
Taking these insights into the professional world of making tourist attractions, there is a need to better understand how the spatial designs of attracting places and objects help experiences. This is in line with Lonsway's understanding of how 'experience economists [Pine and Gilmore, 1999] have come to understand the experimental capacity of spatial design' (Lonsway, 2009: 2) - how places and mobilities can be made enchanting. As a first inspiration, Tolkien argued for the need that the various kinds of designers take part in the enchantment. In other words: Professionals must also enter into the Secondary World and the many realities, absent and present, at play. They need to involve and transcend producerconsumer boundaries. But this also suggests working more with the tension between Erfahrung and Erlebnis, making it productive. McCormack explains a notion of experience (Erfahrung) focused on an immediate - and transitional - thisness. This implies an openness towards multiple realities (including those termed virtual by some) that is connective rather than simply subjective. From the other side, Benjamin with Hetherington's explanation implies a modernist notion of Erlebnis occupied with connections between multiple realities, full of traces making things step into our lives, so that people take possession of things and make experiences their own. And Simmel shows how adventures can be lived out in places through mobilities, connecting worlds, where experiences take place as relational performances. This way the connecting movement (fahren in German) of Erfahrung converts with the real life of Erlebnis in a world occupied with the enchantment of place and mobility.

A genuine example of enchanting spatial designs that has emerged through experimentation can be found at the Viking Ship Museum in Roskilde (see Bærenholdt and Haldrup, 2004; Haldrup and Bærenholdt, 2010). Here, a new museum environment has been created by trial and error, in cooperation between architects and museum professionals, none of whomMcCorma were professional designers of experience sites. The so-called Museum Island (1997) adds an outdoor attraction of building and sailing replica ships as an extra place in addition to the modernist Museum Hall (1969) where the few remains of the sunken Viking ships are exhibited. The Museum Island allows a long-grown museum tradition of experimental archaeology to move from back-stage to front-stage. Building and sailing replica ships has become not only a research method but also a way of engaging and enchanting professionals, volunteers and visitors in other worlds. This way, there is no doubt that the museum director, along with her staff, follows Tolkien in taking part in the enchantment. The director uses musical metaphors to explain how the spatial design of the museum 'tunes the audience and makes people open for experiences' driving back other speculations so that '[o]ne has to give in...'(quoted in Haldrup and Bærenholdt, 2010: 192). Of course, Benjamin would have qualified this and said: 'not us giving in to them, they (things) step into our lives'. And this is also what has happened in the making of the Museum Island as a semi-public place, where people can engage with shipbuilding and sailing within the tradition of Nordic ships. The Museum Island offers a space with open access outside of the museum's opening hours and is much used - and taken possession of also by local people.

The co-performance of visitors is a necessary ingredient in making experiences take place at the Viking Ship Museum but so are also the designed experience sites and artefacts. It becomes an experience of the site, ships, tools and events going on, which are all designed following a modernist concept of using original style tools and methods in ship building but letting everything else stay modern in a robust style. Even across the differences between the Museum Hall and the Museum Island, there is a clear conceptual line, thereby 
making up a specific set of realities. The museum succeeds in connecting worlds, translating the aura of ship remains in the Museum Hall into the trace of real sailing ships at the Museum Island (Bærenholdt and Haldrup, 2004). Replica ships do step into the lives of visitors and locals; a step supported by the museum's concept of, if not obsession with, experimental archaeology. Worlds are connected in a modern setting, where visitors, professionals, volunteers and locals feel at home. But in their presence, there are multiple figural absences: Viking Age life, warfare, trade, tools, myths, symbols - but also the whole Nordic wooden ship building tradition, where most of the ships are in fact either original or replicas of ships from the North Atlantic in the last two centuries. And maybe most importantly, this is first and foremost a site about mobility, about sailing the oceans, and therefore there is plenty of information about several experimental trips, most prominently the fare to Ireland and back of the replica longship The Sea Stallion from Glendalough in 2007-2008. Recently an even longer Viking ship Agir, which turned up as a coincidence during the construction of Museum Island, has been made a mobile exhibition artefact, shown at the Danish National Museum, the British Museum and the Museum of Prehistory and Early History in Berlin in 2013-2015. Meanwhile, the Viking Ship Museum in 2014 showed the exhibition The World in the Viking Age connecting the Nordic Viking Age with the mobile trade patterns through Volga, Persia to China and so on, again enacting histories of mobility and mobile lives. In a typically modern, contemporary way, one of the concepts used to describe the past was 'the network society'; again this is a way of connecting realities, making the past something coming into, and understandable in, our lives.

The kinds of enchantment that can be experienced at a place like the Viking Ship Museum are those of connecting multiple realities, hinting to the absent in the present. Sea mobilities of the past resonate with contemporary mobile lives, so there is connection - but also contrast: The museum is a tranquil place that offers rest and contemplation.

The example of the Viking Ship Museum shows how professionals, volunteers along with visitors and locals have managed to make the site an enchanting experience of place and mobility. There was no direct way to achieve this; much was achieved through learning by doing. It involves a concept of experience that ends in being somehow both Erlebnis and Erfahrung. Like going to a music concert, there is a need for visitors' openness, attention and expectation of experiencing as 'a mixture of being demanding and blasé, of maintaining deception, of tirelessly hoping for that moment of feeling overwhelmed [...]' (Henion, 2001: 14) that can be seen as distraction and Erlebnis. But the museum also plays on a certain kind of thisness requiring visitors to become engaged in a relational performance of Erfahrung resonating with their own mobile lives.

The museum, as other tourist sites, had to experiment to build its attraction. And it is less the result of any coded, analytical insight than pragmatist learning from trying out various designs and solutions. There are no blueprints. Experimenting with designs and evaluating through ethnographical attention to experiences, including one's own, is the way to go, although it requires the intense involvement of the designers taking part. This suggests a way of thinking about the connection between research and design, where they cannot be kept separate. In fact, research works through design, just as design works through research (Bærenholdt et al., 2010: 3; Haldrup and Bærenholdt, 2010: 199). Not only are musicians and archaeologists experimenting with experience when doing their work; research in experience and consumption also needs to do so. 
In French, there is no real distinction between 'experience' and 'experiment'. This can inspire understanding of the designing of experience sites through experiments as deeply involved with the enchantment of experiences. To design spaces tempting people to 'let things step into our lives' and get in the mood of 'feeling overwhelmed' requires from the designer the ability to enter in the realness of the Secondary World and even more worlds. Many people have experiences of touring consumption in sites at which there was no enchantment, that is, places and mobilities not affording experiences. There is room for improvements, to do experimental research that has an impact on making-up enchanting places and mobilities. Taking part in experimenting with experience can produce new, both deep and practical, knowledge.

\section{Conclusion}

Taking an ontological position on experiences as real, made-up and performed, this paper investigated what it takes to perform tourist sites, to make experiences and trigger fascination and fantasy. It dealt with the part of touring consumption that takes place at tourist sites or attractions. To do this, a number of classical theorists such as Simmel and Benjamin were discussed in relation to thoughts from as diverse inspirations as J.R.R. Tolkien on one side and Actor-Network Theory on the other. Enchantment became a key concept for understanding experiences of fantastic places and mobilities, since it was able to account for how multiple worlds or realities are connected in making experiences. This implied not only the Primary and Secondary Worlds of Tolkien, but also the multiplicity of realities suggested by Law and Mol, and Simmel's early but still relevant idea of the living adventurer. The difficult and not so precise concept of experience itself was discussed, first through Hetherington's reading of Benjamin, suggesting that modern experiences are about Erlebnisse rather than Erfahrung, in other words about the distracted, mobile consumer, rather than the contemplation of the producing subject. This tension was later modified, suggesting that the two meanings of experience converge in modern lives.

This way of elaborating the concept of experience is tied into how the paper read Simmel's early elaboration of both mobility and experience, where the realness of experience in second modernity is embedded into mobile lives, and there is a principal openness required to reach any reality to an extent that no one will be able to achieve it. This is a kind of modernist ambivalence that cannot be escaped. Furthermore, the principal possibility of moving to any place only accelerates the need for more and better experiences.

But mobility is not abstract; it is still about going places. Stronger and stronger virtual and imaginative mobilities only enhance the need for physical presence in places, and thereby for physical travel to visit tourist attractions. This way experiences, mobility and place are heavily interconnected concepts; they can hardly be thought of without each other.

Throughout the paper, the most central idea came from Walter Benjamin's notion of the trace that makes people experience not in some other place but in their own space, since worlds get connected. Another way of saying this is to focus on absence-presence, as explained by Hetherington, and Law and Mol. In this case, absence is not total, since it is exactly the connection and management of the absent that becomes the central thing about experiences. Connecting realities across simple notions of absence and presence is at the centre of enchanting experience. 
Experiencing enchantment is a relational accomplishment that requires both the performance of visiting 'experiencers' and the affordance of the spatial design of the place and artefacts visited. The importance of the spatial designs of the tourist sites was exemplified with the case of the Viking Ship Museum in Roskilde, connecting various worlds, places and mobilities into the experience of the visitor. The case was used to discuss how (much) analytical insight could possibly support better spatial designs at tourist attractions. The answers to this modified the question, since it was found that it might well be that deeper understanding of how to make better experiences can be accomplished through pragmatist research together with (for example museum) professionals experimenting with the spatial designs of their attractions. This is a conclusion stressing that conceptual clearness is helpful but not sufficient. There is always a need to deal in detail with the specificities of certain experiences, enchantments, places and mobilities. This way, we can also be sure that our work will never be finished.

The relevance of Walter Benjamin's work to research in consumption is in no way new, but hopefully this paper can inspire others to readdress and revisit classic inspirations like Benjamin, and also Tolkien and Simmel, together with more recent ANT approaches and Hetherington's important work. As suggested in Pine and Gilmore's work, as well as in consultancy and practical work, more solid, deeper and more sophisticated conceptual ideas are helpful when combined with pragmatic learning by doing. Benjamin helps us to remember that consumption is vital and enchanting, not only a machine, and always about place and mobility. It is about our lives, living up with Erlebnisse.

This paper has been developed through a number of presentations since 2010, including a Waagening Geography Lecture in April 2012 and a keynote to the Touring Consumption conference at Karlshochschule International University, Karlsruhe in October 2013. A few passages are similar to arguments in Bcerenholdt (2013). Thanks for very constructive comments and suggestions from anonymous reviewers and the editors.

\section{References}

Amin A and Thrift N (2002) Cities: Reimagining the Urban. Cambridge: Polity.

Andersen B and Harrison P (2010) The promise of non-representational theories. In: Andersen B and Harrison P (eds) Taking-Place: Non-Representational Theories and Geography.Farnham: Ashgate, pp.1-34.

Bærenholdt JO (2012) Enacting destinations: the politics of absence-presence. In: Van der Duim R, Ren C and Jóhannesson GT (eds) Actor-Network Theory and Tourism. London: Routledge, pp.111-127.

Bærenholdt JO (2013) Experiencing mobility: mobilizing experience. In: Witgall S, Vogl G and Kesselring S (eds) New Mobilities Regimes in Art and Social Science. Farnham: Ashgate, pp.287-298.

Bærenholdt JO, Büscher M, Scheuer JD et al. (2010) Perspectives on design research. In: Simonsen J, Bærenholdt JO, Büscher M et al. (eds) Design Research: Synergies from Interdisciplinary Perspectives. London: Routledge, pp.1-15. 
Bærenholdt JO and Granås B (2008) Places and mobilities beyond the periphery. In: Bærenholdt JO and Granås B (eds) Mobility and Place: Enacting Northern European Peripheries. Aldershot: Ashgate, pp.1-10.

Bærenholdt JO and Haldrup M (2004) On the track of the Vikings. In: Sheller M and Urry J (eds) Tourism Mobilities: Places to Play, Places in Play. London: Routledge, pp.78-89.

Bærenholdt JO, Haldrup M and Larsen J (2008) Performing cultural attractions. In: Sundbo $\mathrm{J}$ and Darmer P (eds) Creating Experiences in the Experience Economy. Cheltenham: Edward Elgar, pp.176-202.

Bærenholdt JO, Haldrup M, Larsen J et al. (2004) Performing Tourist Places. Aldershot: Ashgate.

Benjamin W (1998) Kunstværket i dets tekniske reprodurcerbarheds tidsalder. In: W. Benjamin. Kulturkritiske essays. Copenhagen: Samlerens Bogklub, pp.129-158. [Danish translation from the second edition; later to be considered the third edition from 1936 or 1937, of the essay 'The Work of Art in the Age of Mechanical Reproduction', first printed in German 1955, from Gesammelte Schriften, Suhrkamp.]

Benjamin W (2007) Passagevoerket. Vol. 1 and 2. Copenhagen: Rævens Sorte Bibliotek, politisk revy. [Danish translation from the German 1982 Suhrkamp edition of Das PassagenWerk.]

Bennett J (2001) The Enchantment of Modern Life. Princeton, NJ: Princeton University Press.

Bingham N and Thrift N (2000) Some new instructions for travellers: the geography of Bruno Latour and Michel Serrres. In: Crang M and Thrift N (eds) Thinking Space. London: Routledge, pp.281-301.

Braun B and Whatmore S (2010) The stuff of politics: an introduction. In: Braun B and Whatmore S (eds) Political Matter: Technoscience, Democracy and Public Life.

Minneapolis, MN: University of Minnesota Press, pp. ix-xl.

Buck-Morss S (1991) The Dialectics of Seeing. Walter Benjamin and the Arcades Project. Cambridge, MA: MIT Press.

Buciek K (2001) Stedets og rejsens ambivalens [The ambivalence of place and travel]. In: Simonsen K (ed) Rum, Praksis og Mobilitet. Frederiksberg: Roskilde Univeritetsforlag, pp.173-206.

Carù A and Cova B (2003) Revisiting consumption experience. Markerting Theory 3(2): 267-286.

Coleman S and Crang M (2002)(eds) Tourism between Place and Performance. Oxford: Berghahn Books.

Cresswell T (2004) Place: A Short Introduction. Malden: Blackwell. 
Cresswell T (2006) On the Move: Mobility in the Modern, Western World. New York: Routledge.

De Certeau M (1984) The Practice of Everyday Life. Berkeley, CA: University of California Press.

Degen M, Melhuish C and Rose G (2015) Producing place atmospheres digitally:

Architecture, digital visualisation practices and the experience economy. Journal of

Consumer Culture. Epub ahead of print 27 February 2015. DOI:

$10.1177 / 1469540515572238$.

Edensor T (1998) Tourists at the Taj: Perfomance and Meaning at a Symbolic Site. London: Routledge.

Edensor T (2001) Performing tourism, staging tourism. Tourist Studies 1(1): 59-81.

Farías I (2012) Destinations as virtual objects of tourist communication. In: Van der Duim, R, Ren C and Jóhannesson GT (eds) Actor-Network Theory and Tourism: Ordering, Materiality and Multiplicity. London: Routledge, pp.128-145.

Gregson N (2007) Living with Things: Ridding, Accommodation, Dwelling. Wantage: Sean Kingston Publishing.

Haldrup M and Bærenholdt JO (2010) Tourist experience design. In: Simonsen J, Bærenholdt JO, Büscher M et al. (eds) Design Research: Synergies from Interdisciplinary Perspectives. London: Routledge, pp.187-200.

Haldrup M and Larsen J (2009) Tourism, Performance and the Everyday: Consuming the Orient. London: Routledge.

Halkier B (2010) Consumption Challenged. Farnham: Ashgate.

Henion A (2001) Music lovers: taste as performance. Theory, Culture \& Society 18(5): 122.

Hetherington K (2002) Whither the world? Presence, absence and the globe. In: Verstraete G and Cresswell T (eds) Mobilizing Place, Placing Mobility. Amsterdam: Rodopi, pp.173188.

Hetherington K (2007) Capitalism's Eye: Cultural Spaces of the Commodity. New York: Routledge.

Hui A (2012) Things in motion, things in practice: how mobile practice networks facilitate the travel and use of leisure objects. Journal of Consumer Culture 12 (2): 195-215.

Ingold T (2000) The Perception of the Environment. London: Routledge.

Jantzen C (2013) Experiencing and experiences: a psychological framework. In: Sundbo J and Sørensen F (eds) Handbook on the Experience Economy. Cheltenham: Edward Elgar, pp.146-170. 
Jenkins R, Nixon E and Molesworth M (2011) 'Just normal and homely': the presence, absence and othering of consumer culture in everyday imaging. Journal of Consumer Culture 11(2): 261-281.

Jóhannesson GT (2005) Tourism translations: Actor-Network Theory and tourism research. Tourist Studies 5(2): 133-50.

Jóhannesson GT (2007) Emergent Tourism: An Actor-Network Approach to Tourism Economies. PhD Thesis, Roskilde University, Denmark.

Jóhannesson GT and Bærenholdt JO (2008) Enacting place through the connections of tourism. In: Bærenholdt, JO and Granås B. (eds): Mobility and Place: Enacting Northern European Peripheries. Aldershot: Ashgate, pp.155-166.

Jóhannesson GT and Bærenholdt JO (2009) Actor-Network Theory/network geographies. In: Kitchin R and Thrift N (eds) International Encyclopedia of Human Geography, Vol. 1. Amsterdam: Elsevier, pp.15-19.

Kesselring S (2008) The mobile risk society. In: Canzler W, Kaufmann V and Kesselring S (eds) Tracing Mobility. Aldershot: Ashgate, pp.77-102.

Kesselring S and Vogl G (2008) Networks, scapes and flows: mobility pioneers between first and second modernity. In: Canzler W, Kaufmann V and Kesselring S (eds) Tracing Mobility. Aldershot: Ashgate, pp.163-179.

Knudsen BT and Waade AM (2010) Performing authenticity in tourism and spatial experience: Rethinking the relations between travel, place and emotion. In Knudsen BT and Waade AM (eds) Re-Investing Authenticity: Tourism, Place and Emotions. Bristol: Channel View Publications, pp.1-19.

Lash S (1994) Reflexivity and its doubles: structure, aesthetics, community. In: Beck U, Giddens A and Lash S Reflexive Modernization. Cambridge: Polity, pp.110-173.

Latham A (1999) The power of distraction: distraction, tactility, and habit in the work of Walter Benjamin. Environment and Planning D: Society and Space 17(4): 451-473.

Law J (2002) Objects and space. Theory, Culture \& Society 19(5/6): 91-105.

Law J and Mol A (2001) Situated technoscience: an inquiry into spatialities. Environment and Planning D: Society and Space 19(5): 609-21.

Löfgren O (1999) On Holiday: A History of Vacationing. Berkeley, CA: University of California Press.

Lonsway B (2009) Making Leisure Work: Architecture and the Experience Economy. London: Routledge.

Massey D (2005) For Space. London: Sage. 
McCormack D (2010) Thinking in transition: the affirmative refrains of experience/experiment. In: Andersson B and Harrison P (eds) Taking-Place: NonRepresentational Theories and Geography. Farnham: Ashgate, pp.201-220.

Miller D (2010) Stuff. Cambridge: Polity.

Miller D, Jackson P, Thrift N et al. (1998) Shopping, Place and Identity. London: Routledge.

Minca M and Oakes T (2006)(eds) Travels in Paradox. Oxford: Rowman and Littlefield Publishers.

Mol AM (1999) Ontological politics: a word and some questions. In: Law J and Hassard J (eds) Actor-Network Theory and After. Oxford: Blackwell, pp.4-89.

Mol AM and Law J (1994) Regions, networks and fluids: anaemia and social topology. Social Studies of Science 24(4): 641-671.

Mol AM and Law J (2002) Complexities: an introduction. In: Law J and Mol A (eds) Complexities: Social Studies of Knowledge Practices. Durham: Duke University Press, pp.1-22.

Nielsen HP and Møller KT (2014) Studying place practices and consumption through volunteer-employed photography. Journal of Consumer Culture. Epub ahead of print 21 May 2014. DOI: 10.1177/1469540514536195.

Pedersen KM (2010) Flygtige Forbindelser og Midlertidige Mobiliseringer: Om Kulturel Produktion på Roskilde Festival. [Fluid Connections and Temporary Mobilizations: On Cultural Production at the Roskilde Festival.] PhD Thesis, Copenhagen Business School, Denmark.

Pine BJ and Gilmore JH (1999) The Experience Economy: Work Is Theatre and Every Business a Stage. Boston: Harvard University Press.

Pine BJ and Gilmore JH (2007) Authenticity: What Consumers Really Want. Boston: Harvard University Press.

Ren C (2009) Constructing the Tourist Destination: A Socio-material Description. PhD Thesis, University of Southern Denmark, Denmark.

Ritzer G (2005) Enchanting a Disenchanted World, 2nd edition. Thousand Oaks: Pine Forge Press.

Savage M (2000) Walter Benjamin's urban thought: a critical analysis. In: Crang M and Thrift N (eds) Thinking Space. London: Routledge, pp.33-53.

Simmel G (1986, original 1911/23) Das Abenteuer. In: Simmel G. Philosophische Kultur: über das Abenteuer; die Geschlechter und die Krise der Moderne. Berlin: Wagenbachs Taschenbücherei, pp.25-38. 
Sundbo J and Bærenholdt JO (2007) Indledning: Den mangfoldige oplevelsesøkonomi. [Introduction: The multiple experience economy.] In: Bærenholdt JO and Sundbo J (eds) Oplevelsesøkonomi: Produktion, Forbrug, Kultur. [Experience Economy: Production, Consumption, Culture.] Frederiksberg: Samfundslitteratur, pp.9-25.

Svabo C (2008) Artefacts and the performance of an exhibition. Digital Kompetanse, 3(2): 113-29.

Svabo C (2010) Portable Objects at the Museum. PhD Thesis, Roskilde University, Denmark.

Svabo C, Larsen J, Haldrup M et al. (2013) Experiencing spatial design. In: Sundbo J and Sørensen F (eds) Handbook on the Experience Economy. Cheltenham: Edward Elgar, pp.310-324.

Thompson CJ, Locander WB and Pollio HR (1989) Putting consumer experience back into consumer research: the philosophy and methods of existential-phenomenology. Journal of Consumer Research 16(2): 133-146.

Thrift N (2006) Knowing Capitalism. London: Sage.

Tolkien JRR (1997) On fairy-stories. In: Tolkien JRR The Monsters and The Critics: and Other Essays. London: HarperCollins, pp.109-161.

Turner VW (1986) Dewey, Dilthey and drama: an essay in the anthropology of experience. In: Turner VW and Bruner EM (eds) The Anthropology of Experience. Urbana and Chicago, IL: University of Illinois Press, pp.33-44.

Urry J (1995) Consuming Places. London: Routledge.

Urry J (2007) Mobilities. Cambridge: Polity.

Van der Duim R, Ren C and Jóhannesson GT (2012) Tourismscapes, entrepreneurs and sustainability. In: Van der Duim R, Ren C and Jóhannesson GT (eds) Actor-Network Theory and Tourism: Ordering, Materiality and Multiplicity. London: Routledge, pp.26-42.

Veijola S (2006) Heimat tourism in the countryside: paradoxical sojourns to self and place. In: Minca C and Oakes T (eds) Travels in Paradox. Oxford: Rowman and Littlefield Publishers, pp.77-95.

Verstrate G and Cresswell T (2002)(eds) Mobilizing Place, Placing Mobility. Amsterdam: Rodopi.

Wang N (1999) Rethinking authenticity in tourism experience. Annals of Tourism Research 26(2): 349-370. 